\title{
114 スキンプレートが並進振動するテンタゲート式水門の流体関連振動
} Flow-Induced-Vibration of Tainter-gate with Skinplate Parallel Vibration

\section{正 阿南景子（足利工大） 正 石井徳章（阪電通大） ○学 茂木達也（足利工大院）}

Keiko ANAMI, Ashikaga Institute of Technology, 268-1 Omae-cho, Ashikaga, Tochigi 326-8588, Japan Noriaki ISHII, Osaka Electro-Communication University, 18-8 Hatsu-cho, Neyagawa, Osaka 572-8530, Japan Tatsuya MOTEGI, Ashikaga Institute of Technology

\begin{abstract}
As part of the investigation of the dynamic instability of Tainter-gate, the field vibration tests on full-scale operational Tainter-gates were conducted. As a result, the possible existence of a coupled-mode self-excited vibration mechanism, which involves the dangerous dynamic coupling of the whole gate rigid-body rotational vibration with a "parallel" bending of the skinplate, was suggested. This paper presents that the 2-dimensional model test, which was undertaken to confirm the existence of the coupled-mode self-excited vibration with skinplate parallel bending mode.
\end{abstract}

Key Words: Tainter-gate, Flow-Induced-Vibration, Self-Excited Vibration, 2D Model Test, Parallel Bending Vibration

\section{1. はじめに}

大型のダムの水位調節のために、テンタゲート（ラジア ルゲート）が世界中で多数使用されている。断面概略図を 図 1 に示しているように、円弧状のスキンプレートを、ラ ジアルアームを介し、円弧の中心にあるトラニオンピンー 点で支える扇形構造である。このテンタゲートは、ある条 件下で非常に動的に不安定な状態に陥ることがわかってお り、著者らによって、これまでに数多くの研究が行われて きた (1) (3)。その一環として、日本で実用されているテンタ ゲートの振動実地調查を行ったところ、非常に激しい自励 振動が確認された (2)。解析の結果、図 1 に矢印で示すよう に、ゲート全体がトラニオンピン周りに剛体的に回転する 固有振動と、スキンプレートが流水方向にほぼ一様に振動 する二つの固有振動が確認されている。特に重要なことは、 スキンプレートが並進振動する際に、その重心の振動方向 がトラニオンピンの下側を通過することである。同様な固 有振動モードは、米国の実用テンタゲートについての振動 実地調査でも確認されている(3)。この重心の振動方向がト ラニオンピンを通過しないために、スキンプレートの並進 振動が慣性のトルクを介してゲート全体のトラニオンピン 周り㴊体振動と簡単に連成し、ある条件下で激しい自励振 動を引き起こすと考えられる。

本研究では、このようなメカニズムによって連成自励振 動が発生することを確かめるため、小型 2 次元モデルを作 成し、自励振動実験を行った。

\section{2 次元モデルゲート}

作成したモデルゲートの概略図を図 2 に示している。半 径 $250 \mathrm{~mm}$ の円弧の一部を切り取った剛体のスキンプレー トを、その円弧中心にあるトラニオンピン一点で支えてい る。スキンプレートの高さは $266 \mathrm{~mm}$ 、幅は $195 \mathrm{~mm}$ である。 モデルゲート全体の質量は $3.48 \mathrm{~kg}$ である。実機の巻上げワ イヤーの弾性をばね A で代表させている。スキンプレート の並進振動は、スキンプレート背面に設けたスライドベア リングとばね B で代表させた。振動方向を微調整するため に、ピボット軸受を使用している。スキンプレート背面に おもりを取り付け、スキンプレートが振動した時に、その 重心の振動方向がトラニオンピンより $17.7 \mathrm{~mm}$ 下を通過す るようにした。

\section{3. スキンプレート並進振動の確詔}

本モデル実験では、スキンプレートが流水中で並進振動

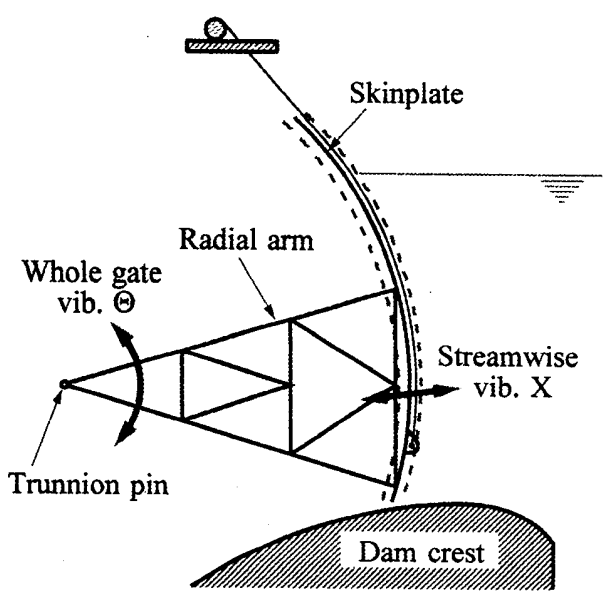

Fig.1 Schematic view of Tainter gate and its natural vibration modes.

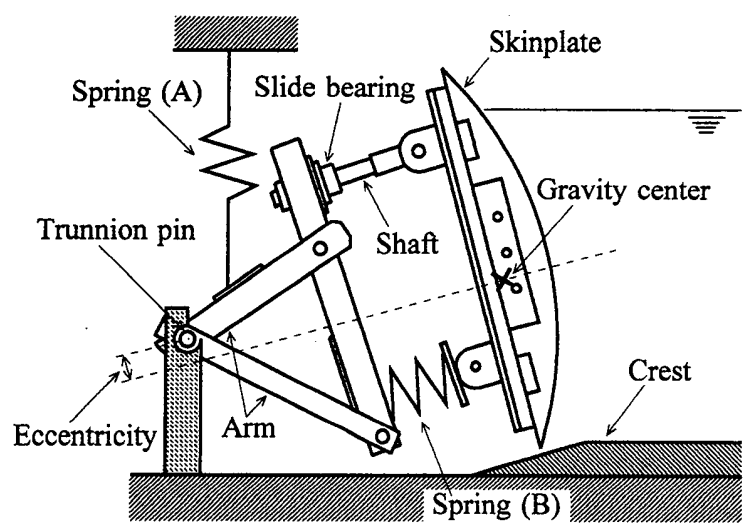

Fig.2 Cross-sectional view of 2-dimensional model gate.

をしているかどうかが非常に大切である。そこで、第一に、 スキンプレートの水中での振動を確認した。図 3 の左側図 に丸枠で示すように、スキンプレート背面の上端部と下端 部に渦電流型の非接触変位計を設置し、水中での流水方向 固有振動を計測した。計測した実時間波形を図 3 の右側に 示している。上端部と下端部で、周期が一致していること が分かる。振幅もほぼ等しく、スキンプレートが並進振動 していることが確認できた。 


\section{4. 自励振動実験}

上流側水位を $250 \mathrm{~mm}$ 、放水口開度を $2 \mathrm{~mm}$ に設定して実 験を行った。水中でのスキンプレート流水方向固有振動数 $\Omega_{\mathrm{nwx}}$ は $4.33 \mathrm{~Hz}$ であった。空中でのゲート全体のトラニオ ンピン周り振動数 $\Omega_{\mathrm{a} \theta}$ を $4.58 \mathrm{~Hz}$ に設定して放水すると、自 励振動が発生した。そのときのゲート下端部の振動波形を 図 4 に示している。上図がトラニオンピン周り(上下)振動 $(\Theta) 、 下$ 図が流水方向振動 $(\mathrm{X})$ である。いずれも $4.18 \mathrm{~Hz}$ で振 動している。このときの発振比(負性減衰比)は、トラニオ ンピン周り振動が 0.012、流水方向振動が 0.014 であった。 振動が成長し定常状態に落ち着いたときの振幅は、トラニ オンピン周り振動が $1.13 \mathrm{~mm}$ 、流水方向振動は約 4 倍の $4.51 \mathrm{~mm}$ であった。

トラニオンピン周り振動数 $\Omega_{\mathrm{a} \theta}$ を $3.19 \mathrm{~Hz}$ から $5.23 \mathrm{~Hz}$ まで 変化させ、同様の実験を行った。そのとき水中振動周波数 を図 5(a)に示している。横軸は空中でのトラニオンピン周 り (上下方向)振動数 $\Omega_{\mathrm{a} \theta}$ である。水中流水方向固有振動数 $\Omega_{\mathrm{nwx}}$ と空中でのトラニオンピン周り(上下方向)振動数 $\Omega_{\mathrm{a} \theta}$ を破線で示している。印がトラニオンピン周り振動、○ 印が流水方向振動である。 $3.19 \mathrm{~Hz}$ から $5.23 \mathrm{~Hz}$ の範囲で、 トラニオンピン周り振動と流水方向振動が同期して自励振 動が発生している。横軸の $\Omega_{\mathrm{a} \theta}$ が $\Omega_{\mathrm{nwx}}$ より小さい $\left(\Omega_{\mathrm{a} \theta}<\Omega_{\mathrm{nwx}}\right)$ 範囲では、同期振動数は横軸の $\Omega_{\mathrm{a} \theta}$ とほとんど同じ值である。 すなわち、流水方向の振動が上下方向の振動に引きずられ て同期している。それに対し、横軸の $\Omega_{\mathrm{a} \theta}$ が $\Omega_{\mathrm{nwx}}$ より大き い $\left(\Omega_{\mathrm{a} \theta}>\Omega_{\mathrm{nwx}}\right)$ 範囲では、データは横ばいになってくる。同 期振動数は破線で示した $\Omega_{\mathrm{nwx}}$ とほぼ同じ值である。これは、 流水方向固有振動数 $\Omega_{\mathrm{nwx}}$ に引きずられる形で同期現象が 起こっていることを示している。さらに横軸の $\Omega_{\mathrm{a} \theta}$ が大きく なると、トラニオンピン周り方向と流水方向振動数は非同 期となり、それぞれ異なった值をとるようになる。

微小振動時の波形から発振比(負性減衰比)を求めた結果 を図 $5(b)$ に示している。横軸の $\Omega_{\mathrm{a} \theta}$ が大きくなるにしたがっ て発振比は徐々に大きくなる傾向が見られた。

振動が成長し、定常状態に落ち着いたときの振幅を図 $5(\mathrm{c})$ に示している。横軸の $\Omega_{\mathrm{a} \theta}$ が破線で示した $\Omega_{\mathrm{nwx}}$ に近いと ころで、振幅が大きくなっていることが分かる。その付近 では、図 4 にも示した様に、トラニオンピン周り振動の振 幅 $\Theta_{0}$ に比へ、流水方向振動の振幅 $\mathrm{X}_{0}$ が非常に大きくなっ ている。

\section{5. おわりに}

実地調查の結果、スキンプレートが流水方向に並進振動 をする場合にも、トラニオンピン周り振動と簡単に連成し、 激しい自励振動が発生することが示唆されていた。本研究 では、その固有振動モードを再現した小型 2 次元モデルを 作成し、自励振動実験を行った。その結果、スキンプレー トが並進振動する場合にも非常に激しい自励振動が発生す ることが確認できた。

本研究は、日本学術振與会科学研究費補助金の補助を得 て行ったものである。

\section{文献}

(1) Anami, K., Dissertation submitted to Osaka Electro-Communication University, March 2002.

(2) Anami, K., et.al, Proc. of ASME PVP Conf., PVP2007-26543, (Jul. 2007).

(3) Ishii, N. et.al., Proc. of WaterPower XVI, No.188, (Jul.2009).

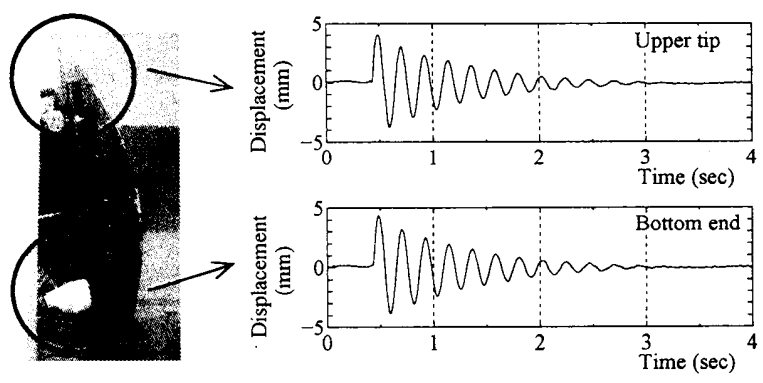

Fig.3 In-water streamwise parallel vibration of the skinplate.

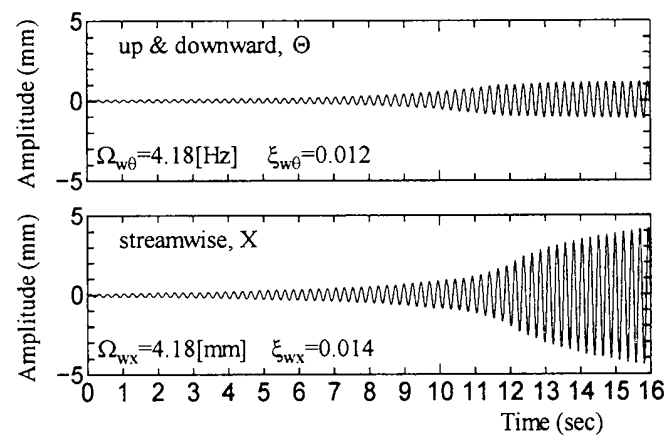

Fig.4 Self-excited vibration waveforms measured at the skinplate bottom end $\left(\Omega_{\mathrm{nwx}}=4.33 \mathrm{~Hz}, \Omega_{\mathrm{a} \theta}=4.58 \mathrm{~Hz}\right)$.
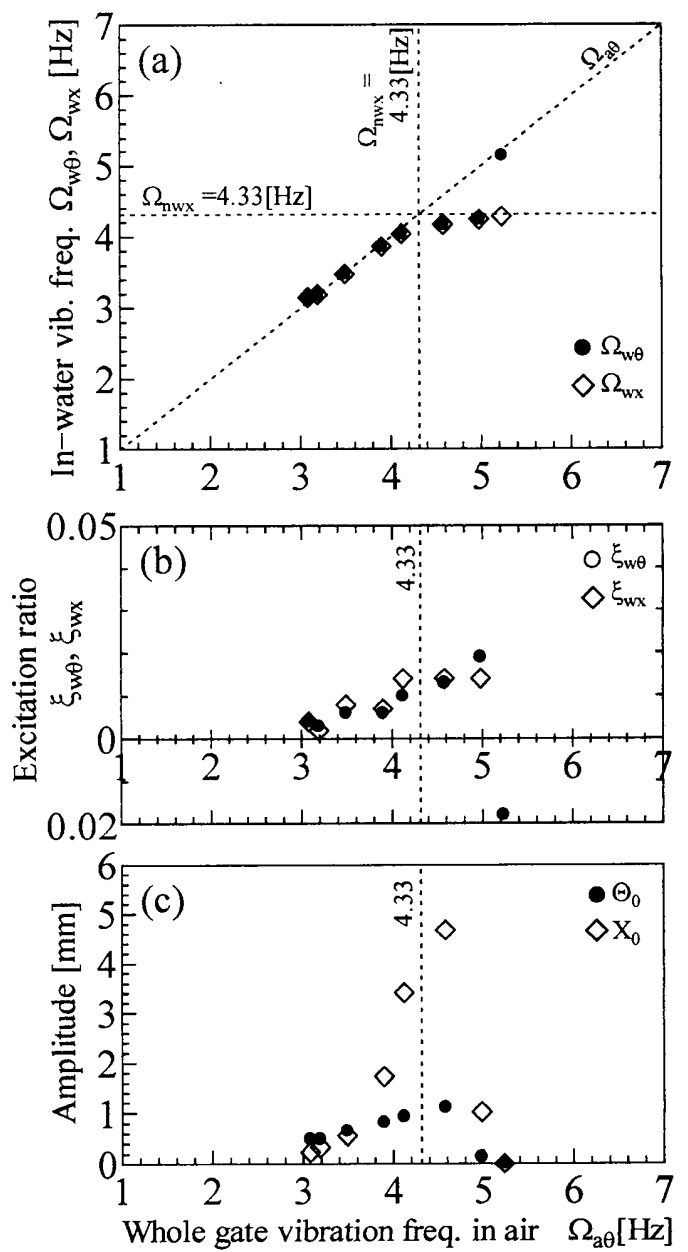

Fig.5 Test results of the model gate: (a) in-water vibration frequency, (b) excitation ratio, (c) vibration amplitude. 